\title{
Phytochemical analysis and antibacterial activity of extract from lantana camara l. leaves
}

Bondy Lourenço ( $\sim$ bondylourenco@gmail.com)

Faculty of Health Sciences - Lurio University https://orcid.org/0000-0002-0705-7160

Asimbawe Kiza

Faculty of Health Sciences - Lurio University

Abrão Amândio João

Faculty of Health Sciences - Lurio University

Clemência Félix Odala Niconte

Faculty of Health Sciences - Lurio University

Pompílio Armando Vintuar

Faculty of Food and Agricultural Sciences-Rovuma University

Eusébio André Pedro Gwembe

Rovuma University

Lázaro Gonçalves Cuinica

Faculty of Natural Sciences, Mathematics and Statistics - Rovuma University

Research Article

Keywords: Antibacterial activity, extract phytochemical analysis, Lantana camara L.

Posted Date: January 26th, 2021

DOI: https://doi.org/10.21203/rs.3.rs-151542/v2

License: (c) (i) This work is licensed under a Creative Commons Attribution 4.0 International License. Read Full License 


\section{Abstract}

Background: Currently, several studies are being conducted to test antibacterial activity of various medicinal plants, in attempt to develop new antibiotics or to potentiate the action of antibiotics of known clinical use. In this research, phytochemical analysis and in vitro antibacterial activity of leaf extracts of Lantana camara $L$ were performed.

Methods The extracts were obtained through maceration with $90 \%$ ethanol. In phytochemical analysis, alkaloids, flavonoids, tannins and saponins were identified using specific reagents for each class. The antibacterial activity was analyzed using the disk diffusion method according to Kirby-Bauer, against Escherichia coli and Staphylococus aureus.

Key findings The diameters of the inhibition halos varied between 0.7 and $12 \mathrm{~mm}$, with an average of $8.26 \mathrm{~mm}$ for strains of S. aureus and there was no inhibition for E. coli. The results showed a significant difference between the inhibition halos and the tested concentrations for $\mathrm{S}$. aureus.

In conclusion L. camara leaf extracts are rich in bioactive compounds and have a good antibacterial potential against $S$. aureus and not for $E$. coli. And there was no relationship between the concentration of the extract and the diameter of the halo of inhibition of the evaluated microorganism.

\section{Background}

Lantana camara L. is a species that belongs to the verbenaceae family, native to Brazil and Uruguay, typical of Africa and tropical and subtropical America [1, 2]. This species was introduced as an ornamental in several countries such as, Mozambique, Cape Verde, South and East Europe, East and West Africa, Madagascar, Mauritania, North America, Caribbean, India, China, Asia, Australia and New Zealand, and is currently considered one of the most invasive weeds and harmful in the world [3, 4]. However, L. camara is used for several medicinal purposes, since all its parts have biological or pharmacological activity, such as antimicrobial, fungicide, insecticide, nematicide, antioxidant, anti-inflammatory and diuretic activity [2].

In Mozambique, the species L. camara is called m'bulimuthi, chauwunké, chamarenke, n'teja, n'toja or n'tuja, and in Brazil the vernacular name of the species is cambarazinho or lantana-cambará $[5,6]$. It is a shrub, with branched stem, from $30 \mathrm{~cm}$ to $2 \mathrm{~m}$ or a little higher, has a very penetrating and characteristic aroma. Its branches are quadrangular, light brown, with small thorns, opposite leaves, very thick, rough, ovate, aromatic. Inflorescence in corimbiform chapters, of small, sessile flowers, of various colors such as yellow, pink, purple or orange. When ripe, the fruits have a bluish color and initially green, where they are toxic as a means of plant defense $[2,6,7]$.

Secondary metabolites are important for the adaptation and propagation of plant species. The main classes of metabolites identified in plant species are nitrogenous compounds, phenolic compounds and terpenoids [2].

In a study carried out in Brazil, on the phytochemical and antimicrobial prospecting of L.camara and Lantana trifoliate extracts, using the maceration method and the disk diffusion method, verified for the extract of the dried leaves of L. camara, a diameter of $7 \pm 0$ mm inhibition zone, also for $E$. coli and $S$. aureus. While, for Lantana trifoliate, the inhibition zone was $13.66 \pm 1.15 \mathrm{~mm}$ for $S$. aureus and no inhibitory zone was detected for $E$. coli. Phytochemical analyzes indicate the presence of alkaloids, cardiotonic glycosides, volatile coumarins, flavonoids, tannins, saponins, triterpenes and / or steroids and anthracene derivatives [6].

Studies by Bhargaya et al. (2008) and Nayak et al. (2008) proved that the methanol extract of L. camara leaves has an antimicrobial action and that it was effective in healing gastric ulcers and preventing the development of duodenal ulcers in rats. The infusion of the leaves is used in the treatment of fever, eczema and rash. Its fruits are useful in tumors and rheumatism [8, 9].

Bacterial resistance to antibiotics is considered as a set of adaptation equipment that makes a bacterium resist the action of the drugs to which they are being exposed $[10,11]$. Currently, bacterial resistance is associated with several environments and, in addition to occurring in hospital environments, it can reach qualified people [12]. The use of combined therapy is an alternative that can be adopted in an attempt to solve the problem of bacterial resistance [13]. However, the excessive and inappropriate use of antibiotics, poor hygiene conditions, continuous flow of travelers, the increase in immunocompromised patients and the delay in the diagnosis of bacterial infections have favored the increase in resistance [12].

A S. aureus species is the most pathogenic of its kind, a cause of a wide variety of infections in humans, from spines and boils to pneumonia, food poisoning and infections in surgical wounds, and is also a cause of major hospital infections [14,15]. This species is Gram-positive coconut with clusters, immobile and not spore-forming, belonging to the micrococcaceae family. It is characterized by the production of the enzyme coagulase, positive catalase and fermentation of mannitol $[10,13]$.

E.coli is the most common and clinically important species of the genus, causing more than $80 \%$ of all community-acquired urinary tract infections, as well as many hospital infections, and gastroenteritis in developing countries $[15,16]$. This microorganism is a Gram-negative bacillus evaluated as a latose fermenter, facultative anaerobic and oxidase-negative [15].

In several studies, the resistance of these pathogens to antibiotics of first choice has been found, including chloramphenicol and ampicillin. As they are, the main causes of diarrheal diseases, which are the second main cause of infant mortality worldwide [17].

In view of this great therapeutic problem for public health, currently, several studies are being carried out to test the antibacterial activity of various medicinal plants, in an attempt to develop new antibiotics or to enhance the action of antibiotics of known clinical use [18]. Therefore, the main objective of this work is to analyze the chemical composition and antibacterial activity of the extract of the leaves of L. camara against $E$. coli and $S$. aureus. 


\section{Methods}

\section{Vegetable matter}

The collection of plant material was carried out in July 2019, in the neighborhood of Natikiri - city of Nampula $\left(15^{\circ} 07^{\prime} 09.5^{\prime \prime} \mathrm{S} 39^{\circ} 12^{\prime} 56.3^{\prime \prime} \mathrm{E}\right)$. The identification of the species L. camara was made by comparing its characteristics with other species in the literature, and, with the confirmation of Pompilio Vintuar (Ph.D in Agricultural Sciences - Agroecology, Professor at Universidade Rovuma). This time, the exsiccate was prepared and preserved in the herbarium of the Pharmacy course at the Faculty of Health Sciences at Lúrio University. After the collection, the damaged parts of the plant material were separated, washed with water to remove impurities, dried in the sun for seven days, and then crushed and sieved, from which $200 \mathrm{~g}$ of the fine, homogeneous powder were obtained $[6,19]$.

\section{Obtaining vegetable extract}

The preparation of the plant extract was carried out at the Laboratory of Ethnobotany and Phytochemistry at the Faculty of Health Sciences of Lúrio University. Through the maceration method, where $200 \mathrm{~g}$ of dry leaf powder were left in contact with $2 \mathrm{I}$ of $90 \%$ ethanol, in the proportion of $1 \mathrm{~g} / 10 \mathrm{~mL}$ and, occasionally stirred for 7 days, in a dry environment, without direct light and the average daily temperature of $26^{\circ} \mathrm{C}$. Subsequently, it was filtered with cotton, twice, and the ethanolic extract was obtained $[6,19]$.

Once the ethanolic extract was obtained, it was divided in half, where one part was dried in the oven at $105^{\circ} \mathrm{C}$, for 8 hours, and the other part, dried in the rotary evaporator at reduced pressure at $420 \mathrm{C}$, for 6 hours. Then, the yield for both drying methods was calculated, based on the following mathematical expression [20]:

$R e=m_{d e} / m_{l e}-100 \%$, where: $R e=$ dry extract yield; $m d e=$ mass of the dry extract; $m l e=$ mass of the liquid extract.

\section{Phytochemical analysis}

The dry extracts of the leaves of L. camara were used in phytochemical analysis to identify the following secondary metabolites: alkaloids, flavonoids, tannins, saponins and anthraquinones. These metabolites were identified according to the availability of reagents, following the methods of phytochemical analysis, such as:

For tannins: $1 \mathrm{~mL}$ of extract diluted with water in the proportion of 1: 2 was added in a test tube, then 2 drops of $10 \%$ lead acetate were added. In this reaction, the formation of a dense reddish brown precipitate indicates the presence of tannins [21,22]. With the same procedure, a control test was performed with only the solvent without extract.

For alkaloids: the extract is dissolved in $6.25 \mathrm{ml}$ of $5 \% \mathrm{HCl}$ and heated for 10 minutes. After cooling, it was filtered through cotton. Then, 5 drops of Wagner's reagent (iodine / potassium iodide, [I2 / KI]) were added. The presence of a slight turbidity or precipitate, respectively purple to orange, white to cream and brown, highlights the possible presence of alkaloids [21, 22].

For saponins: $2 \mathrm{ml}$ of ethanolic extract was added in a test tube, then $5 \mathrm{ml}$ of distilled water was added, stirred vigorously for 2 to 3 minutes and left to stand for 20 minutes. The existence of persistent and abundant foam suggests the presence of saponins [21, 22].

For flavonoids: the extract was diluted 1: 5 with water, then $5 \mathrm{ml}$ of diluted extract was placed in a test tube and a drop of $2 \%$ ferric chloride was added to the test tube wall. In this reaction, the presence of a color that varies between green, yellow-brown and violet, showed the presence of flavonoids [23]. Then, a control test was performed with only the solvent.

For anthraquinones: $0.5 \mathrm{~g}$ of the extract was weighed in a watch glass and 3 drops of $0.5 \% \mathrm{NaOH}$ were added. The presence of yellowish color shows the presence of anthraquinones in the reduced form or reddish color that indicates the presence of anthraquinones in the oxidized form [23].

\section{Analysis of antibacterial activity}

An analysis of the antibacterial activity of the ethanolic extract of the leaves of $L$. camara, was carried out using the diffusion method according to KirbyBauer with some adaptations, at the Public Health Laboratory of the province of Nampula. E. coli strains obtained from a stool sample grown on TCBS agar (thiosulfate, citrate, bile and sucrose) and $S$. aureus strains obtained from a wound sample with pus grown on blood agar were used. Bacteria were suspended with $0.9 \% \mathrm{NaCl}$, with a density close to the standard scale of 0.5 of Mac Farland. Then, using the sheet technique, the suspension was sown on Muller Hington agar. Then, the $0.4 \mathrm{~cm}$ diameter filter paper discs were impregnated, in triplicate, with concentrations of $200 \mathrm{mg} / \mathrm{ml}, 300 \mathrm{mg} / \mathrm{ml}, 400 \mathrm{mg} / \mathrm{ml}$ and $500 \mathrm{mg} / \mathrm{ml}$ of the ethanolic extract of the leaves of L. camara, and, for negative control test, the discs impregnated with $90 \%$ ethanol solvent were used. Then, the discs were placed on Muller Hington agar, $2 \mathrm{~cm}$ apart and incubated in the oven for 24 hours at $37^{\circ} \mathrm{C}$. After incubation, the diameter of the halos in millimeters was determined with the help of a millimeter ruler $[24,25,26]$. 


\section{Statistics}

The analysis of the results was performed based on the SPSS version 20.0 statistical package, for data processing, using the following statistical tests: Shapiro-Wilk test, Kruskal-Wallis $\mathrm{H}$ test and Mann-Whitney U test for two groups [27].

\section{Results}

The extraction yield was $4.61 \%$, and the dry extract in the Greenhouse $\left(105^{\circ} \mathrm{C}\right)$ was $3.92 \%$. In phytochemical analysis, the presence of alkaloids, tannins, flavonoids, saponins was identified. There was a negative result for the quinones (Table 1).

Table 1: Classes of metabolites identified in the extract of the leaves of $L$. camara according to the method of drying the extract.

\begin{tabular}{lll}
\hline Secondary metabolites & Greenhouse dry extract & Dry extract on rotary evaporator \\
Alkaloids & + & + \\
Tannins & + & + \\
Flavonoids & + & + \\
Saponins & + & + \\
Quinones & - & - \\
\hline
\end{tabular}

Note: (-) absent; (+) present.

Source: Own authorship (2020)

The results of the antibacterial analysis showed diameters of the inhibition halos that varied between 0.7 to $12 \mathrm{~mm}$ for the concentrations of $200 \mathrm{mg} / \mathrm{mL}$ and $300 \mathrm{mg} / \mathrm{mL}$, respectively, and had the total mean of the diameters of the inhibition halos equal to $8.26 \mathrm{~mm}$ for strains of S. aureus. However, for strains of E. coli, no inhibition halo was detected for all concentrations of the extract (Table 2).

Table 2: Concentrations of the ethanolic extract of L. camara and the diameters of the halos of inhibition against S. aureus and E. Coli

\begin{tabular}{|c|c|c|c|c|}
\hline \multicolumn{2}{|l|}{ Concentration (mg / mL) } & \multicolumn{3}{|c|}{ Diameters of inhibition halos (in mm) } \\
\hline & & S. aureus & & coli \\
\hline $\mathrm{C} 1$ & 200 & $0,70 \pm 0,00$ & - & \\
\hline $\mathrm{C} 2$ & 300 & $12,00 \pm 0,00$ & - & \\
\hline C3 & 400 & $10,00 \pm 0,00$ & - & \\
\hline $\mathrm{C} 4$ & 500 & $10,33 \pm 0,58$ & - & \\
\hline \multicolumn{5}{|l|}{ S. aureus } \\
\hline Number of samples (n) & Minimum & Maximum & Media & Standard deviation \\
\hline 12 & 0,70 & 12,00 & 8,2583 & 4,63258 \\
\hline
\end{tabular}

Source: Own authorship (2020)

Note: (-) inhibition halo not detected; (C) concentration; \pm standard deviation.

The Shapiro-Wilk test for $\mathrm{S}$. aureus data, had $\mathrm{P}<0.05$, indicating that the data do not have a normal distribution. Thus, the non-parametric test was performed to find out if there is a difference between the groups, such as the Kruskal-Wallis Test $\mathrm{H}$ which had $\mathrm{p}=0.015$, accepting the alternative hypothesis, that there is a statistically significant difference between the distribution of the diameters of the halos of inhibition in mm and the concentrations in mg / $\mathrm{ml}$ for $\mathrm{S}$. aureus, and the Mann-Whitney $\mathrm{U}$ test analyzed for each two groups, had $\mathrm{P}<0.05$, which proves, again, that there is a difference between the means groups.

The Spearman correlation coefficient between the concentration in $\mathrm{mg} / \mathrm{ml}$ and the diameter of the inhibition halo was equal to 0.34 , indicating that there was a weak correlation, that is, there was no relationship between the concentration of the extract and the diameter of the halo inhibition of the evaluated microorganism.

\section{Discussion}

The yields obtained in the two drying methods are considered good for research aimed at searching for potential biologically active natural products, as is the case of this study [28].

The presence of secondary metabolites in the analyzed extract, mainly tannins and flavonoids, indicates a possible antimicrobial activity [24]. Several factors can influence the production of secondary metabolites, such as the time of plant collection, circadian rhythm, development, temperature, precipitation, ultraviolet radiation, nutrients, altitude, atmospheric elevation, plant age, mechanical stimuli or pathogen attack [29].

The mean diameter of the inhibition halos was considered positive, as described in the studies for products that inhibit bacterial growth, producing inhibition halos equal to or greater than $8 \mathrm{~mm}$ in diameter [30].

When the extract shows a difference in activity against Gram-negative and Gram-positive bacteria, it may be because of the constitution of the bacterial cell wall and the components of the plant extract [31]. Several authors state that there is a relationship between the amount of tannins and the activity towards Gram-positive bacteria, whose cell structure is more rigid, the chemically less complex cell wall and less lipids in relation to the Gram-negative bacteria [24, 32]. 
The disk diffusion method is more used to determine the relative potential of extracts or essential oils and to establish their antimicrobial spectrum, because it facilitates the use of different strains compared to the extract [33].

The Spearman correlation coefficient was equal to 0.34 , indicating that there was no relationship between the concentration of the extract and the diameter of the inhibition halo of the evaluated microorganism. Also, this result was noted in a comparative study of screening techniques to assess the antibacterial activity of crude extracts of plant species and pure substances, where it was found that there was no proportionality between the concentration of the extracts and the diameter of the inhibition zone of microorganisms [34].

\section{Conclusion}

According to the results demonstrated, it is concluded that the extract of the leaves of L. camara is a rich source of biologically active compounds analyzed in this study, namely tannins, flavonoids, alkaloids and saponins and presented a good antibacterial potential against $S$. aureus and not for $E$. coli. And there was no relationship between the concentration of the extract and the diameter of the halo of inhibition of the evaluated microorganism.

\section{Declarations}

\section{Conflict of interest}

There is no conflict of interest.

\section{Acknowledgements}

We would like to thank Natálio Daudo (Public Health Laboratory of the province of Nampula) for their continuing support. We would like to acknowledge the Andarusse Pedro Chande for support.

\section{Authors' contributions}

BL oversaw study conception, design of the study, study conduct, data collection, data analysis and manuscript production. AK was involved in study conception, design of the study, data collection, including the production of the study protocol. AJ participated in conducting the study and in approving the manuscript. CN supervised the conduct of the study, evaluation of antibacterial activity, data analysis and approval of the manuscript. PV was involved in the identification of the plant, study design and approval of the manuscript. EG participated in conducting the study and in the approval of the manuscript. LC provided senior scientific information and oversight on study conception, study design, data collection, phytochemical analysis and manuscript production. All authors read and approved the final manuscript.

\section{Funding}

This work was not funded.

\section{Availability of data and materials}

The data sets used and / or analyzed during the current study are available from the corresponding author, upon reasonable request.

\section{Ethical approval and consent to participate}

Not applicable.

\section{Consent for publication}

Not applicable.

\section{Competitive interests}

The authors declare that they have no conflicting interests.

\section{References}

1. Sousa, Erlânio Oliveira, et. al. Actividade antibacteriana e interferência de Lantana camara L. e Lantana montevidensis (Spreng.) Briq. na resistência de aminoglicosídeos. Revista Brasileira de Biociências. [internet]. 2011 jan./mar [cited 2020 Dec 20]; 9(1): 1-5. Available in: http://www.ufrgs.br/seerbio/ojs/index.php/rbb/article/viewFile/1525/991.

2. Bezerra, José Weverton Almeida, et al. Potencial Medicinal De Lantana camara L. (Verbenaceae): Uma Revisão. Cadernos de Cultura e Ciência. [Internet]. 2016 Out [cited 2020 Dec 20]; 15(1): 82-92. Available in: http://periodicos.urca.br/ojs/index.php/cadernos/article/view/1079.

3. Hiasa, Grazielle de Oliveira. Caracterização farmacognóstica das variedades de Lantana camara Monografia (Graduação em Farmácia). Faculdade de Pindamonhangaba, Pindamonhangaba. [Internet]. 2013 [cited 2020 Dec 20]. Available in:

http://177.107.89.34:8080/jspui/bitstream/123456789/187/1/GrazielleHiasa.pdf. 
4. Pagule, Carlos Elias. Levantamento das espécies invasoras nas formações vegetais em zonas de ocorrência de fogo no Parque Nacional do Limpopo. Dissertação (Dissertação em Maneio e Conservação da Biodiversidade). Universidade Eduardo Mondlane, Maputo. [Internet]. 2016 [cited 2020 Dec 20]. Available in: http://196.3.97.27/handle/123456789/257.

5. De Koning, J. Checklist of vernacular plant names in Mozambique: Registo de nomes vernäculos de plantas em Moçambique. Wageningen Agricultural University Papers, Universidade Eduardo Mondlane, Maputo. [Internet]. 1993 [cited 2020 Dec 20]; 2-93. Available in: https://edepot.wur.nl/282848.

6. Goes, Thiago Zucov de Faria, et al. Prospecção fitoquímica e antimicrobiana dos extratos de Lantana Camara L. e Lantana Trifolia L. Saber Científico, Porto Velho. [Internet]. 2016 [cited 2020 Dec 20]; 5(1): 1- 11. Available in:https://www.arca.fiocruz.br/handle/icict/28105.

7. ZENIMORI, Sadaka; PASIN, Liliana AAP. Aspectos da biologia floral de Lantana (Lantana camara L.). Encontro Latino Americano de Iniciação Científica, X. e Encontro Latino Americano de Pós-Graduação. [Internet]. 2006 [cited 2020 Dec 20]; 6,136-139. Available in:

http://cronos.univap.br/cd/INIC_2006/inic/inic/02/INIC0000207_ok.pdf.

8. Bhargava, Sushil, et. al. Evaluation of Antimicrobial Potential of SudarshanChurna: A Polyherbal Formulation. Iranian Journal of Pharmacology and Therapeutics. [Internet]. 2008 [cited 2020 Dec 20]; 7(2): 185-187. Available in:http://ijpt.iums.ac.ir/browse.php?

a_id $=168 \&$ slc_lang=en\&sid=1\&printcase $=1 \& \mathrm{hbnr}=1 \& \mathrm{hmb}=1$.

9. Nayak, Shivananda, al. Investigation of wound healing activity of Lantana camara L. in Sprague dawley rats using a burn wound model. International Journal of Applied Research in Natural Products. [Internet]. 2008 March/April [cited 2020 Dec 20]; 1(1): 15-19. Available in:

https://scholar.google.com.br/scholar?

as_sdt=1,5\&q=Nayak+Raju+,+Ramsubhag+A,+of+wound+healing+activity+of+Lantana+camara+L.+in+Sprague+dawley+rats+using+a+burn+wound+mo PT.

10. Bertoncheli, Claudia de Mello, et. al. Uma revisão sobre metalo-- $\beta$-lactamases. Revista Brasileira de Ciências Farmacêuticas. [Internet]. 2008 out-dez [cited 2020 Dec 20]; 44( 4): 577-99. Available in: <http://www.scielo.br/scielo.php?script=sci_arttext\&pid=S1516-93322008000400005\&lng=en\&nrm=iso>.

11. Nogueira, Hadison Santos, et. al. Antibacterianos: principais classes, mecanismos de ação e resistência. Unimontes Científica. [Internet]. 2016 jul./dez [cited 2020 Dec 20]; 18(2): 96-108. Available in: http://www.ruc.unimontes.br/index.php/unicientifica/article/view/523.

12. Guimarães, Denise Oliveira, al. Antibióticos: importância terapêutica e perspectivas para a descoberta e desenvolvimento de novos agentes. Quim. Nova. [Internet]. 2010 [cited 2020 Dec 20]; 33(3): 667-679. Available in: <http://www.scielo.br/scielo.php? script=sci_arttext\&pid=S0100$40422010000300035 \&$ lng=en\&nrm=iso>.

13. Fernandes, Prabhavathi. Antibacterial discovery and development-the failure of success?. Nature biotechnology. [Internet]. 2006 [cited 2020 Dec 20$]$; 24(12):1497-1503. Available in: https://www.nature.com/articles/nbt1206-1497.

14. Tortora, Gerard Jerry, et. al. Microbiologia:Microbiologia. Porto Alegre: Artmed. 2012

15. Nogueira, Joseli Maria da Rocha; Miguel, Luceny de Faria Souza. Bacteriologia. Fundação Oswaldo Cruz/EPSJV. [Internet]. 2009 [cited 2020 Dec 20]; $222-$ 397. Available in: https://www.arca.fiocruz.br/bitstream/icict/15170/2/cap3.pdf.

16. Murray P.R., Rosenthal K. S. E. \& Pfaller, M. A. Microbiologia Médica, 6ª edição, Elservier Editora Ltda., Rio de Janeiro. Brasil. 2010.

17. Sigauque, Betuel, al. Análise situacional e Recomendações: Uso e resistência aos antibióticos em Moçambique. Center for Disease DynamicsEconomics. [Internet]. 2015 [cited 2020 Dec 20]; 1, 1-15. Available in:https://www.researchgate.net/profile/evangelina_namburete/publication/281906350situationalanalysis-and-recommendations-useandresistancetoantibioticsinmozambique/links/55fddeb708ae07629e31ec37/ situational-analysis-andrecommendations-use-and-resistance-to-antibiotics-in-mozambique.pdf.

18. Aliaga, Fabiola Colquechagua, et. al. Enterobacterias productoras de betalactamasas de espectro extendido en muestras fecales en el Instituto Nacional de Salud del Niño, Perú. Revista Peruana de Medicina Experimental y Salud Pública. [Internet]. 2015 [cited 2020 Dec 20];32(1): 26-32. Available in: http://www.scielo.org.pe/pdf/rins/v32n1/a05v32n1.pdf.

19. Simões, Cláudia Maria Oliveira, al. Farmacognosia: da planta ao medicamento. Porto Alegre: Editora da UFSC. 2007.

20. Rodrigues, TS, et. al. (2011). Métodos de secagem e rendimento dos extratos de folhas de Plectranthus barbatus (boldo-da-terra) e P. ornatus (boldomiúdo), Bras. Pl. Med. [Internet]. 2011 [cited 2020 Dec2 20]; 13, especial, 587-590. Available in: <http://www.scielo.br/scielo.php? script=sci_arttext\&pid=S1516-05722011000500014\&lng=en\&nrm=iso>.

21. Zucula, Cremildo Vitorino. Avaliação in vitro da actividade antifúngica de extractos de plantas no controlo de fitopatógenos. Monografia (Licenciatura em Química), Universidade Eduardo Mondlane, Maputo. [Internet]. 2011 [cited 2020 Dec 20] Available in: http://monografias.uem.mz/handle/123456789/829.

22. Cuamba, Fernando Ângelo. Avaliação da actividade antimicrobiana dos extractos das raízes e folhas de combretum molle. Monografia (Licenciatura em Química),Universidade Eduardo Mondlane, Maputo. [Internet]. 2014 [cited 2020 Dec 20]. Available in: http://monografias.uem.mz/handle/123456789/894. 
23. Mouco, Gabrielle al. Controle de qualidade de ervas medicinais. Revista Biotecnologia Ciência \& Desenvolvimento. [Internet]. 2003 julho/Dezembro [cited 2020 Dec 20]; 31, 68-73. Available in:file:///E:/MANUAIS\%20METODOLOGICOS/Artigo\%20Analise\%20fitoquimica/MOUCO\%20Biotecnologia.pdf.

24. Gadéa, Suzana Ferreira Magalhaesl. Avaliação da actividade antimicrobiana do extracto bruto e suas fracoes de glischrothamnus ulei (molluginaceae) do semi-arido baiano. Dissertação (Dissertação em Biotecnologia), Universidade Estadual de Feira de Santana, Feira de Santana. [Internet]. 2008 [cited 2020 Dec 20]. Available in: http://www2.uefs.br/ppgbiotec/portugues/arquivos/corpo\%20discente/mestrado/2006/suzana_ferreira_magalhaes_gadeadissertacao.pdf.

25. Xavier, Glaydson Jhonnys Queiroz, et al. Exame da ação antibacteriana do óleo de abacate: contribuições possíveis para a saúde e o meio ambiente. IV congresso internacional das ciências agrárias, COINTER-PDVAgro. 2019 [cited 2020 Dec 20]; 1-6.

26. Amparo, Tatiane Roquete, et al. Métodos para avaliação in vitro da actividade antimicrobiana de plantas medicinais: a necessidade da padronização. [Internet]. 2018 [cited 2020 Dec 20]. Available in: http://www.repositorio.ufop.br/handle/123456789/10844

27. Margotto, Paulo Roberto. Estatística computacional: Uso do spss (statistical package for the social sciences): o essencial. Escola Superior de Ciências da Saúde (ESCS)/SES/DF. [Internet]. 2012 [cited 2020 Dec 20]. Available in: https://scholar.google.com.br/scholar?hl=pt-

PT\&as_sdt=0\%2C5\&q=MARGOTTO+PR\%2C+Estat\%C3\%ADstica+computacional+uso+do+SPSS+\%28Statistical+package+for+the+socialSciences $\% 29 \% 3$

28. Fernandes, Izabela G. et. al. Processo de extracção para a construção de uma colecção de extractos de espécies da mata Atlântica. Blucher Biochemistry Proceedings. [Internet]. 2015 [cited 2020 Dec 20]; 1(1): 60-61. Available in: http://pdf.blucher.com.br.s3-sa-east1.amazonaws.com/biochemistryproceedings/v-jaibqi/0094.pdf.

29. Gobbo-Neto, Leonardo; LOPES, Norberto P. Plantas medicinais: fatores de influência no conteúdo de metabólitos secundários. Quím. Nova. [Internet]. 2007 [cited 2020 Dec 20]; 30(2):374-381. Available in: <http://www.scielo.br/scielo.php? script=sci_arttext\&pid=S0100$40422007000200026 \&$ Ing $=$ en\&nrm=iso>.

30. Catão, Raissa Mayer Ramalho. Actividade antimicrobiana e efeitos biológicos de riparinas sobre bactérias e fungos leveduriformes. Tese (Doutorado em Concentração em Farmacologia), Universidade Federal da Paraíba, João Pessoa. 2007.

31. Loguercio, Andrea Pinto, et. al. Actividade antibacteriana de extrato hidro-alcoólico de folhas de jambolão (Syzygium cumini (L.) Skells). Ciência Rural. [Internet]. 2005 mar- abr [cited 2020 Dec 20]; 35(2): 371-376. Available in: <http://www.scielo.br/scielo.php? script=sci_arttext\&pid=S0103$84782005000200019 \&$ Ing=en\&nrm=iso>. ISSN 1678-4596.

32. Khan, et. al. Antimicrobial activity of Symplocoscochinchinensis. Phytotherapy. 2001 [cited 2020 Dec 20]; 72(7): 825-828.

33. Rios, Jose-Luis; Recio, Maria Carmen. Medicinal plants and antimicrobial activity.Journal of Ethnopharmacology. [Internet]. 2005 [cited 2020 Dec 20 ]; 100 , 80-84. Available in:

https://www.researchgate.net/profile/Maria_Recio3/publication/7778137_Medicinal_plants_and_antimicrobial_activity/links/5a0acf22a6fdccc69ed8214 origin=publication_detail.

34. Alves, Everton Giovanni et al. Estudo comparativo de técnicas de screening para avaliação da atividade anti-bacteriana de extratos brutos de espécies vegetais e de substâncias puras. Quím. Nova. [Internet]. 2008 [cited 2020 Dec 20]; 31(5): 1224-1229. Available in: <http://www.scielo.br/scielo.php? script=sci_arttext\&pid=S010040422008000500052\&lng=en\&nrm=iso> 